\title{
Intellectual Fascism
}

\section{Per Engdahl and the Formation of 'New-Swedish Socialism'}

\author{
Lena Berggren \\ Assistant Professor, Umeå University, Sweden \\ lena.berggren@historia.umu.se
}

\begin{abstract}
The focus of this article is the ideological formation of so called 'New-Swedish Socialism', an indigenous form of fascist thought formulated by the Swedish ideologue Per Engdahl (1909-1994) in the early 1930s. New-Swedish Socialism should not be equated with either Italian-styled Fascism or National Socialism, but must be seen as an original form of fascist thought. This fascist variant can be described as comparatively flexible, low-key and intellectual. The present analysis of the formation of NewSwedish Socialism follows the model for ideological analysis suggested by the British political scientist Michael Freeden. Freeden's analytical mode defines an ideology in terms of a core cluster of interrelated and ineliminable political concepts which are essentially contestable. Starting from a definition of generic fascism and using the core concepts that can be identified from this definition, the presence, de-contestation and interrelatedness of these core concepts within New-Swedish Socialism is studied and analyzed. This article addresses whether New-Swedish Socialism can correctly be labelled fascist as well as capturing its special character as a fascist variant in its own right. The study has been limited to the ideological formation process in the early and mid-1930s but Engdahl remained an important influence on Swedish as well as European fascism throughout his life.
\end{abstract}

\section{Keywords}

Sweden - Swedish fascism - interwar period - Per Engdahl - ideological formation fascist variants - Nysvenska Rörelsen

The aim of this article is to examine the ideological platform of the Swedish fascist ideologue Per Engdahl (1909-1994) during his formative years in the 
early and mid-193os. Engdahl was the leader and founder of the so called NewSwedish movement which has been one of the major fascist movements in Sweden since the 1930s. The New-Swedish movement was not a political party but can best be characterized as a rather elitist political club. It did not contest elections and its membership was unremarkable in terms of numbers. The movement and its leader nevertheless played an important role within the Swedish ultra-nationalist framework up until Engdahl's death and had an influence far beyond the ultra-nationalist environment where it was ideologically rooted.

From an international perspective, the ideological platform of ' $\mathrm{New}$-Swedish Socialism' is also interesting since the movement in the 1950s became one of the more prominent agents of the attempts to revive European fascism through its involvement in the formation in $195^{1}$ of the Europäische Soziale Bewegung (ESB) which had its headquarters in Engdahl's home town Malmö. The ESB programme which was accepted in 1953 was written by Engdahl, and he was also the first editor of the organisation's paper Nation und Europa, which was in circulation until 2009. In the mid-1950s the ESB had members from a number of European countries and the involvement in the ESB meant that the New-Swedish movement thrived during this decade.

The present analysis takes inspiration from the model of ideological analysis that has been suggested by Michael Freeden. ${ }^{1}$ Freeden proposes that any political ideology consists of a number of essentially contestable concepts. What makes a specific ideology unique and different from others is the composition of a number of core concepts which can be considered un-eliminable or necessary. This ideological core constitutes a cluster of interrelated concepts which influence each other, and it is thus important for the analysis of ideology to take this interrelationship into account. The concept of 'liberty' for instance can be a core concept in both socialism and liberalism, but due to the influence of other concepts in the core cluster, it can be given decisively different meanings - it is essentially contestable. The core concepts of an ideology are supplemented by peripheral concepts which are not essential to the ideology and also more bound to the specific context. One way of catching sight of ideological development over time, is to foster an awareness that concepts can perform a sluggish form of 'travel' from the periphery to the core or the other way around, thus slowly reshaping the ideology.

1 Michael Freeden, Ideologies and Political Theory: A Conceptual Approach (Oxford: Clarendon Press, 1998). A concise presentation of Freeden's model can be found in Ideology: A Very Short Introduction (Oxford: Oxford University Press, 2003). 
I have elsewhere proposed to define generic fascism as an ultra-nationalist revolutionary ideology with syncretic and holistic pretentions aiming at a rebirth of the national community which would result in a radically new society and a New Man. ${ }^{2}$ Following Freeden's model, this gives us eight fascist core concepts ('ultra-nationalism', 'revolution', 'syncretism', 'holism', 'rebirth', 'national community', 'new society' and 'New Man'), each of which needs to be further qualified given the co-dependence of the core concepts. Here, I will examine if these concepts are present in the political thought of Per Engdahl, how they are related and qualified and if there are any other concepts that could be considered belonging to the un-eliminable core of New-Swedish Socialism.

Apart from being seen as one of the core concepts of fascism, the term ultranationalism will be used as a blanket-term denoting a number of interrelated ideological forms such as fascism and the interwar radical right which are united through a general anti-democratic position as well as a far-reaching nationalism which, according to Roger Griffin, "go beyond" and hence reject, anything compatible with liberal institutions or with the tradition of Enlightenment humanism which underpins them.' ${ }^{3}$ To Griffin's definition of the term I would like to add that an ultra-nationalist position, apart from being anti-liberal and anti-democratic, also contains a drive not only to safeguard national interests but also to (re)create a national people's community and in doing so it includes a strong racist potential.

The usefulness of the term 'ultra-nationalism' is twofold. First, it suggests the nature of the prime ideological kinship between fascism and the radical and authoritarian right (far-reaching nationalism) as well as the decisive difference between the radical and authoritarian right and mainstream conservatism after the democratic break through (the rejection of liberal institutions, universal suffrage and parliamentary democracy). Second, by using the blanketterm ultra-nationalism rather than 'extreme right', we avoid falling into the trap of perceiving fascism as rightist, which it is not. The fascist project was, and still is, an attempt at finding an ideological third way that is neither right nor left, or perhaps rather, in relation to the syncretism I ascribe this ideology in my definition of it, both at the same time. ${ }^{4}$

2 This definition has been influenced by the work of above all Roger Griffin, Roger Eatwell and George L Mosse, and has been discussed in Lena Berggren, 'Den svenska mellankrigsfascismen - ett ointressant marginalfenomen eller ett viktigt forskningsobjekt?' Historisk Tidskrift 122 (2002): 427-44.

3 Roger Griffin, The Nature of Fascism (London: Routledge, 1993), 37.

4 See further Roger Eatwell, 'On Defining the "Fascist Minimum”: The Centrality of Ideology,' Journal of Political Ideologies 1 (1996): 303-19. 


\section{Per Engdahl: A Biographical Sketch}

Per Engdahl was born in Jönköping in 1909. ${ }^{5}$ He was brought up in a puritan tradition which involved a deep respect for authority, viz. king, state and clergy. The family belonged to the conservative and nationalist upper middle class, and the young Engdahl was brought up in a large town house with a number of servants. The family had a substantial library, and Engdahl was introduced to books and reading at an early age. He got his first schooling in the town's upper secondary grammar school. Here he spent time not only with children from his own social background, but also children from the working class. According to his autobiography, this gave him invaluable insights into the life of the working class, and also respect for socialist ideals and the social democratic demands for economic and social reform. ${ }^{6}$ Politically, he describes his formative teenage years during the early 1920 s as characterised by fear of the implications of the Russian Revolution. He also describes an increasing distrust in liberal parliamentary democracy and its capacity to solve current socio-economic problems. This scepticism was transformed into political enthusiasm after the March on Rome, and Mussolini quickly became a political role model for him.

In 1928, Engdahl began his university studies in Uppsala. He started off with history, moved on to political science and received his Licentiate in political science in $1938 .^{7}$ Shortly after arriving in Uppsala, he joined the Italian-styled fascist party Sveriges Fascistiska Kamporganisation [SFKO; Sweden's Fascist Combat Organisation], which formed its Uppsala branch in February 1928 with Engdahl as one of its more prominent activists. ${ }^{8}$ During 1928 and 1929, partly due to increased personal contacts with Nazi circles in the north of Germany, the SFKO became increasingly influenced by German Nazism. Engdahl found this change of role-model undesirable, and together with his closest associates he left the movement and formed Nysvenska Förbundet [The New-Swedish Federation]. According to his autobiography, the most important ideological reason for this was his rejection of the strong Nazi emphasis on race. However,

5 Biographical information taken from Engdahl's auto-biography Fribrytare i folkhemmet (Stockholm: Cavefors, 1979) and Heléne Lööw, Nazismen i Sverige 1924-1979: Pionjärerna, partierna, propagandan (Stockholm: Ordfront förlag, 2004), 46-66.

6 Engdahl, Fribrytare ifolkhemmet, 26-27.

7 The Licentate is a higher academic degree that is slightly less comprehensive than the Doctorate but still contains a fair amount of original and independent research.

8 See further Lena Berggren, 'Swedish fascism - Why bother?' Journal of Contemporary History 37 (2002): 395-417. 
as we shall see, Engdahl can by no means be considered a non-racist and it is also clear that he embraced anti-Semitic sentiments. Yet his particular understanding of these issues was different from the Nazi position.

In 1930, a split within the organisation led Engdahl and a number of his fellow student activists in Uppsala to form Föreningen det Nya Sverige [The NewSwedish Association]. This became the starting-point of the independent New-Swedish movement, and up until 1937, when the New-Swedish movement was merged with the radical right Sveriges Nationella Förbund [SNF; The Swedish National Federation], Engdahl ran his own independent political movement which presented itself as an alternative to Nazism. The merger with the SNF was however short-lived, and from the autumn of 1941 the NewSwedish legacy was transferred to Svensk Opposition [Swedish Opposition] which after the war returned to its roots and was renamed Nysvenska Rörelsen [NSR; The New-Swedish Movement]. In 1932, the organisation started the weekly paper Vägen Framåt [The Road Forward] which, alongside Engdahl's books and pamphlets, was to become the chief mouthpiece of the movement. Right from the start, Engdahl argued that the New-Swedish movement was to work more as a political club or lobby organisation than a political party, trying to influence other political movements as well as public opinion. Engdahl thus cultivated connections with numerous other ultra-nationalist organisations both in Sweden and abroad.

There has to date been very little research done on the organisation, finances and membership of the New-Swedish movement. It is thus difficult to say how large the movement was. That it was influential in its time, at least during the interwar period, is however a safe conclusion. The movement played an important role within the wider ultra-nationalist movement in Sweden through Engdahl's extensive network. Engdahl was also noticed, and quite often respected, within the more established political debate in Sweden. ${ }^{9}$

At least during the interwar period, Engdahl preferred the company of people sharing his social background. He had few contacts with the proper Nazi parties which had a more cross-class following and where he could have come into contact with political activists from the working class. ${ }^{10}$ It can thus be suggested that Engdahl, despite bold declarations of affinity with the working class, constructed his political ideology from within a largely academic, intellectual and socially homogenous context.

\footnotetext{
9 Personal file on Per Engdahl in the Archives of the Secret Police, The Swedish National Archive, Stockholm. See also Fredrik Lund, Akademisk fascism: Per Engdahls kontaktnät under 1930-talet (Unpublished paper, Uppsala University, 2003).

10 Lööw, Nazismen i Sverige, 253-85.
} 


\section{New-Swedish Socialism and its Enemies}

The term New-Swedishness was coined by Engdahl and his closest associates after the break with the SFKO in the spring of 1930. According to Engdahl's autobiography, the group wanted a name that signalled a nationalist standpoint anchored in tradition, but which also indicated a radical renewal of society as well as independence from both fascism and Nazism. ${ }^{11}$ This characterisation of the ideology of the group was soon to be qualified as 'New-Swedish Socialism', a self-proclaimed label that Engdahl and his associates were to use up until the late 1940s, when the organisation, due to the onset of the Cold War which drastically changed the connotations of political terminology, dropped the reference to socialism and characterised its programme as simply NewSwedish or corporatist. ${ }^{12}$

To Engdahl, socialism was to be equated with community, and this was first and foremost manifested in what he labelled the 'people's community'. The people's community was a national, class-less community. To Engdahl, 'true' socialism would not be achieved through class struggle and the victory of the working class over the bourgeoisie, but through the abolition of the class struggle altogether and its replacement with class cooperation. Accordingly, Engdahl saw Marxism and communism as enemies of 'true' socialism since they not only acknowledged but encouraged class struggle. Accordingly, the first step toward a socialist society had to be the defeat of communism and Marxism. But in order for the defeat of communism not to be a Pyrrhic victory, 'the struggle against communism has to be a struggle against the root and origin of communism, capitalism.13 Furthermore, the struggle for socialism had to be a struggle against parliamentary democracy, which meant that not only were communism and Marxism considered anti-socialist but social democracy as well: 'If socialism is community, class struggle and socialism are incompatible. Parliamentary democracy always contains political parties who fight each other. Party battles are class struggles in disguise. Parliamentary democracy must thus be equated with class struggle, and can therefore not be socialist. So when social democracy turns to parliamentarism, it has abandoned the road to socialism. ${ }^{14}$ In effect, this meant that the only viable road to socialism

\footnotetext{
11 Engdahl, Fribrytare ifolkhemmet, 84-85.

12 Ibid., 188.

13 Per Engdahl, Vad vi vilja! Sanningen om nysvenskheten (Uppsala: Riksförbundet det Nya Sverige, 1934), 10. This and following quotes from Engdahl has been translated from Swedish by the present author.

14 Engdahl, Vad vi vilja!, 8.
} 
proper, i.e. community, was through struggle against capitalism, democracy and all 'non-fascist' forms of socialism. This struggle aimed at the political, economic and social reordering of society and state into a corporate society and a powerful national state which Engdahl labelled the 'people's state.' ${ }^{15}$

So far, a number of enemies of New-Swedish Socialism have been identified. To these, we must also add liberalism. To Engdahl, all of these alien powers had contributed to the depraved modern society that he saw around him, but the emergence of liberalism, capitalism, Marxism and democracy had not been useless. Rather, he saw them as part of historical development in general and as such they were essential:

It must nevertheless be emphasised, that democracy has had its specific historical role. When the old state proved itself unable to lead the economic development along the furrows that were ploughed by technological innovation but instead tied itself to doomed social groupings, democracy became that form through which the new social classes could freely develop and through mutual struggle for power find their natural standing within industrial society. This process is however at the moment more or less completed, and the social preconditions for the existence of democracy have thus been removed. ${ }^{16}$

Here, it is clear that Engdahl considered democracy to be out-dated and proven ineffective. But Engdahl did not suggest a reactionary reversion to authoritarian rule. The simple reason for this was that history, according to his basically Hegelian view on the nature of history, could never turn back. The only possible way was forward, and the future corporate people's state was accordingly seen as post-democratic. Similarly, liberalism, Marxism and capitalism constituted important building-blocks in the historical development that had led up to the present, but were in the interwar period passing their zenith.

Engdahl's writing is not very clear on this point, but he seems to think that this degenerative process could have been countered through decisive political action around the turn of the century, had it not been for the upheaval of the First World War. The war itself brought death and destruction to Europe on a scale never before imagined, and the outcome of the peace treaties, especially

15 See further Lena Berggren, 'Building a New society: Ideas on Social Revolution and the Conception of the People's Community in Interwar Swedish Fascism,' Ideas in History 2 (2007): 115-41.

16 Per Engdahl, Från den industriella revolutionen till det korporativa samhället (Uppsala, 1932), 19 . 
the Versailles treaty, sealed the fate of Europe. There was now no turning back from social, cultural, economic and political degeneration and, ultimately, ruin. Europe was crumbling under its own weight. ${ }^{17}$

This created in Engdahl a sense of living in a transition period characterised by unrest and upheaval, an era of decadence and weakness which could only be terminated through a political and spiritual reawakening from within the national community:

Revolution - that becomes the rallying motto of New-Swedish socialism. But not the bloody upheaval of the streets, not the revolt of the subhuman against order and culture, but the revolt of moral rejuvenation, national rebirth and socialist affinity against spiritual and material misery, a revolution of the Superman in a time of enervation and listlessness. We can not build on the established order, for its foundation is decayed. We must tear down the old and with courageous innovative spirit take on what is new. The New-Swedish movement is revolutionary; it is a revolution of political and moral pioneering. ${ }^{18}$

The New-Swedish movement thus sought a slow but grinding revolution that should be conducted in accordance with historical tradition in order not to disrupt more than necessary. Revolution was, as the quote above also shows, necessary since contemporary society had decayed too far to be salvaged - it had to be recreated completely. Revolution and reform were not contradictory political concepts, but mechanisms of political change situated at opposite poles of a continuum.

If we return to Michael Freeden's model for ideological analysis, we can see that the concept of revolution in the case of Engdahl's (and certainly most fascists') political vision is indeed one of the un-eliminable core concepts, but it is being charged with a very specific meaning through the interplay with other core concepts. And in Engdahl's case, the most important factor to take into account in order to fully understand why he talks about a revolution and how this revolution was thought to evolve is his understanding of history and historical change.

\section{Political Change and Historical Tradition}

Sustainable political change had to be built from the bottom, and this had to be done in accordance with history, tradition and the national spirit of the

\footnotetext{
17 Engdahl, Från den industriella revolutionen, 20-23.

18 Engdahl, Vadvi vilja!, 19.
} 
people. Political change was not seen as an inevitable consequence of historical development but was the result of the interplay between tradition and an activist elite:

Historical development has its given preconditions, it is framed by the limitations of material necessities, but from a certain point numerous and in content widely different phenomena could evolve. History is not a predestined and mechanical development; it is a chain where the causality is determined by living and irrational personality. It is not down to coincidence or invincible natural law but to the will and power of the European elite if the new time that is approaching is to become a fruitful era on the road of white culture toward higher values, or if the arch of civilization will crumble under its own weight and crush that part of the world on which its foundation is laid. ${ }^{19}$

Engdahl did not have a clear-cut deterministic view on history despite the acknowledgement that historical development followed certain laws. If one is to label Engdahl's view on history it would be as Hegelian. Engdahl saw history as a struggle between opposites, and these opposites frequently took on unmistakably metaphysical characteristics. He saw the rise of high cultures as transitory. Even if historic development was seen as in one sense repetitive and governed by 'eternal' entities such as the metaphysical concept of the nation and its close relative the Volksgeist, historical change could not be captured in any simple formula, and could not be predicted. Furthermore, history contained steady and calm periods as well as sudden leaps, and revolutionary upheavals were thus seen as natural ingredients of historical development that occurred in particular at the dawn of new eras when a clean break with the past was necessary. ${ }^{20} \mathrm{Or}$, in Hegelian terms, revolution could be a way of forging the synthesis between the thesis and anti-thesis of a previous historical period and thus start history anew.

Since political revolutions are man-made, was there any way of knowing if an upheaval was productive or destructive? According to Engdahl, there was. As long as a political upheaval was conducted in accordance with historical tradition, it could be considered productive. Any political change should be made with the best interest of the nation in mind since 'The Nation' was perceived as an historical entity that had to be safeguarded in order to ensure sound historical development. What follows is that political steps taken in the

19 Per Engdahl, Det nya Sverige: Utkast till ett politiskt program (Uppsala, 1931), 3.

20 See for instance Per Engdahl, Sverige och det tjugonde århundradet (Stockholm: Holger Schildts förlag, 1934), 308-09. 
opposite direction, away from national unity and national prosperity toward internationalism, class struggle and materialism, were not only politically flawed, but un-natural and destructive.

The revolutionary thrust of fascism should be understood, in this particular case, in relation to the nationalist fervour of the ideology. Here, we see how the concept of ultra-nationalism, combined with a Hegelian view on history, influences and forms the concept of revolution within the core of Engdahl's fascism by determining why revolution is necessary and what it is supposed to achieve. And here we find one of the more decisive differences between Marxist revolutionary ideology and fascist revolutionary ideology. The fascist revolution was perceived as a nationalist cross-class revolution, whereas the Marxist revolution was a class revolution with potentially international implications. The aim of both revolutions was the creation of a New Man and a New Society, but the different directions of the revolutionary thrust lead to different human ideals and, in particular, different societal ideals or utopias.

The revolutionary thrust of Marxism and communism was quite obvious to Engdahl, and this helps explain why he, over time, developed an increasingly aggressive anti-communist agenda. The communist threat of a revolutionary upheaval was, due to its potential magnitude, a much greater threat to the nation than liberal or social democratic reform could ever be. Combined with the wide-spread and historically persistent fear of Russian aggression against Sweden, this proved to be a toxic mixture of ideological and traditional anti-communism.

The aim of the fascist revolution can be described, in Engdahl's political thought, as an attempted restoration and revitalisation of the nation as a metaphysical force as well as a political entity, a rescue mission to salvage the nation from the degenerative forces of liberalism, democracy, Marxism and capitalism. But since history could not go backwards, this project for national rebirth had to be a thrust forward - the nation was not to be resuscitated, it had to be born anew. But what constituted this new-born nation?

\section{Political Foundations}

In order to understand Engdahl's ideas about the nation, we must turn to what he considered its basic foundations - society and state. According to Engdahl it is not until a thorough understanding of these concepts is gained that a strong political programme for the future can be constructed. We have already concluded that socialism for Engdahl is equivalent to community, and it is thus not surprising to find a basic Aristotelian conception of the human as a Zoon 
Politicon, a political animal, at the core of Engdahl's conception of society. Human beings are dependent on each other for their development and growth, and through history an increasing level of division of labour has developed in order to make human life easier but also more fulfilling. This division of labour and responsibility is what Engdahl means by society. ${ }^{21}$

Engdahl criticised Locke's liberal theory of the state of nature and the development of the social contract which codified universal natural law and natural rights - there were no such things as natural rights and laws since these basic rules of society were always manufactured by man. Furthermore, the laws and rights given to man in a specific society had to be in accordance with the nature of the people and nation in question, and the morals that were codified in the law had to be in accordance with the morals of the nation and the national spirit or the Volksgeist. These morals and the national spirit were also interconnected with Christian values and the Lutheran faith. ${ }^{22}$ Engdahl claims that it is the responsibility of the powerful state to make sure 'that the judicial concepts always are in accordance with the moral concepts [of the people].23 This shows thatEngdahl rejected thevery basic foundations of liberalismand Enlightenment humanism and thus clearly embraced an ultra-nationalist standpoint.

There is however one parallel between Engdahl and Locke in the emphasis of labour as a driving force in society and the insistence that the result of one's labour should not be exploited by someone else, but is the property of its proprietor. ${ }^{24}$ But where this is considered a natural, and thus universal, right within the liberal tradition, in Engdahl's view this right is limited to 'civilized' peoples and nations.

The concept of labour is also connected to Engdahl's notion of freedom: 'Freedom is the right of every human, every nation, and every cultural community to develop their individual potential to the highest possible perfection unrestricted by all outer limitations, and within the frame-work of a living culture be able to make the largest possible personal contribution. ${ }^{25}$ Freedom

21 Engdahl, Det nya Sverige, 6.

22 On the relation between Lutheranism and fascism in interwar Sweden, see further Lena Berggren, 'Completing the Lutheran Reformation: Ultra-nationalism, Christianity and the Possibility of "Clerical Fascism" in Interwar Sweden,' in Clerical Fascism in Interwar Europe, ed. Matthew Feldman, Marius Turda and Tudor Georgescu (Abingdon \& New York: Routledge, 2008), 91-102.

23 Engdahl, Det nya Sverige, 25.

24 Further on the importance of labour and the principle of the 'ennoblement of labour' within Swedish interwar fascism at large, see Berggren, 'Building a New Society', 125-29.

25 Per Engdahl, 'Frihet men inte kaos!' Vägen Framåt 1 (15 October 1932). Emphasis added by the present author. 
therefore insists not only rights but also commitments, and freedom should not be gained simply by personal development, since it consists of a combination of rights leading to personal development, and active, altruistic action in favour of society as a whole. In accordance with this view on freedom, liberal democracy becomes nothing but the decomposition of freedom since it lacks this element of individual responsibility for the whole of society and thus ends up in cultural and moral depravation and decay. But in order to make the right, altruistic choices and thus become genuinely free, humans need strong guidance:

We believe that the whole works best when everyone gets his or her share. Democracy and capitalism has shown that an order that aims to bring the principle of freedom alive will not grow spontaneously but has to be organised from above. That is why we claim the right of the national elite to rule; that is why we dare to claim that social discipline is the best protection for old-aged Western freedom! ${ }^{26}$

In order to protect freedom, it thus becomes the duty of the movement not only to once and for all remove capitalism, liberalism and democracy, but also to create a strong state. This self-appointed task was not only a mission to safeguard what was perceived as freedom proper; it was also a moral task and freedom becomes heavily dependent on duty. It is no surprise that Engdahl's New-Swedish Socialism, like fascism in general, relies on deontological ethics. In order for an action to be ethical, it must be based on a sense of duty, and the most important duty in this particular context is the duty to the nation and the national community which ultimately creates a new form of heroism:

The living generation is but a bridge between the future and the past; that spiritual and material culture that enables our high standard of living is the fruit of the labour of our predecessors ... and it is our indispensable duty to leave this inheritance undiminished to future generations. A man of duty is that ideal toward which our nationalist vision leads, an ideal born from our conception of the nation as an organism that has survived through the ages.... The shallowness of modern culture has appeared in all its nudity, and an explorative youth is now turning to something new, a foundation that can give life direction and meaning. That is why an ethics of duty must be one of the fundamental principles of the new era. ... In the wake of duty ethics, heroism follows. The heroic ideal disciplines, but it also encourages to 
power charge and energy. Heroism is the leader's ethics of the men of will, but it can also ennoble the life of the simplest pauper to a life of triumph in the spirit of duty fulfilment. ${ }^{27}$

In order for society - a practical system to organise the social and economic division of labour - to work there is the need for a state that can regulate the social and economic structures and interactions within it. And the more complex the society, the bigger the need for a strong regulating and directive power. Since the current level of societal complexity was considerable, the need for a strong state was greater than ever, contrary to what Engdahl saw around him. ${ }^{28}$

The strong state thus derived its powers from its function as a regulating and directive power over society, but also, as we have seen, from its function of safeguarding freedom and moral values. In effect, the state had the potential of becoming an incarnation of political ethics, which means that everything that the state does is good and ethically justifiable since the state itself is a moral entity. That is, as long as the strong state is aligned with the interest of the nation and the national community, and here we see that Engdahl is clearly influenced by Italian Fascism.

Just as the state is unimaginable without its territory, it is unimaginable without its people. And since the people is embodied by its history, tradition, culture, language and race, the people becomes the embodiment of all national values. The people become the bridge between state and nation. Engdahl describes the state as 'not only a social and economic regulator; it is also the political leader of the nation and as such it must also demand the subjugation of the individual in the interest of the whole.'29

From this, it should be clear that to Engdahl, the nation was something different from and larger than the state and its territory, as it was and still is to fascists in general. It was seen as a living organism where the whole was larger than the sum of its individual parts, and as a living organism it was considered to be 'a super-individual essence [that] has its own being and its own historical mission.' ${ }^{30}$ The echo of romanticist thought is quite tangible, and Engdahl also admits indebtedness to the romantics. When discussing the romanticist legacy, however, he is very careful to point out that New-Swedish Socialism is modern and that the corporate state is originally socialist. ${ }^{31}$ Here, we see the

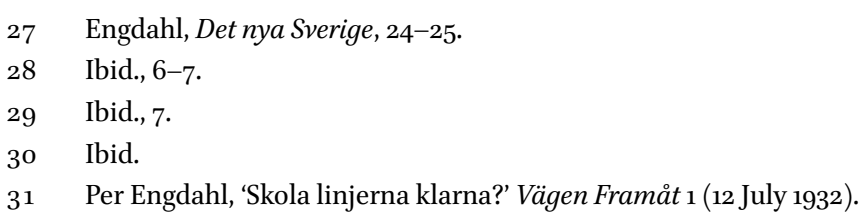


holistic pretentions that forms part of my definition on fascism in play. We also see how these holistic pretentions in the form of an organic view on the nation are qualified by the fundamental ultra-nationalist starting-point.

To sum up the discussion on Engdahl's political foundations, it can be concluded that he distinguishes between society and state, and while these two entities are part of what constitutes the nation they are also conditioned by the nation. In order to thwart the current development and create a new people's community (which would also enhance the level of freedom), state, society and nation had to be brought into organic alignment with each other. We have also touched upon Engdahl's views on ethics, and in that context come into first contact with his ideals for a New Man. This ideal is permeated with deontological ethics; the New Man was to be dutiful and self-sacrificing. But did he have to be a 'blond beast'? In order to find that out, we will now turn to Engdahl's ideas on race.

\section{The People's Community: A Racial Unit?}

In the literature on fascism, it is often pointed out that one of the decisive differences between German-styled National Socialism and Italian-styled Fascism was the Nazi obsession with race. Italian Fascism included elements of racist and anti-Semitic thought, but these played a decisively less prominent role than they did in German Nazism. If we imagine a scale which describes the intensity of racist propaganda and the importance of the racial factor within fascist ideology, with Italian Fascism and German Nazism as the two poles, and try to position Engdahl on this scale, New-Swedish Socialism would end up somewhere in the middle, moving over time further towards the Nazi position. It can and should be clearly stated from the start that NewSwedish Socialism was both racist and anti-Semitic. Nevertheless, issues of race and, especially, anti-Semitism are not frequently discussed during the early 1930s either in Engdahl's own publications or in the movement's journal Vägen Framåt. Also, the tone in the few instances where the issue of race and 'the Jewish question' is discussed was not very aggressive. This changes during the 1930s, and anti-Semitic propaganda becomes much harsher, especially during the war. ${ }^{32}$

32 This judgement is based on the present author's perusal of Vägen Framåt and Engdahl's other writings over a much longer period than is focused in this article. My judgement is also supported by the collected work of Heléne Lööw. 
According to Engdahl, the nation is a community of soil, culture, blood, state and destiny, but he does not fully acknowledge the nation as a racial community. Even if the Swedish nation is considered perhaps the most racially homogenous nation of Europe, Engdahl is also quite clear that much of what he labels 'white western culture' is racially mixed. He even claims that quite a few geniuses have arisen from racial mixing between the Nordic and Alpine races. He argues, however, that in order for racial mixing to have a positive impact on the national culture, it must take place on a small scale and only involve closely related, 'higher' races. Any racial mixing among 'the depths of the people' is detrimental, and will ultimately lead to the destruction of the nation. $^{33}$

Especially vulnerable from this perspective was the rural farmers' population, and here we see a streak of 'Blood and Soil' mysticism in Engdahl. Farmers were considered the racial 'spine' of the nation and also that part of the population which had the strongest ties to historical tradition. Modern development, however, meant that farmers faced both the temptations of the modern city, and economic hardship due to an ever-increasing inflow of cheap imported goods. Strengthening the agrarian sector through policies like price regulation and programmes for self-sufficiency was thus not only vital as part of the New-Swedish economic policy, but also as a means of defending the purity and quality of the race. ${ }^{34}$ It should be pointed out, however, that despite this strand of Blood and Soil mysticism, Engdahl was very much in favour of the agricultural sector undergoing technical modernisation.

There was thus cause for tending to the racial quality of the people. The movement's programme from 1934 contained demands for raised public funding for further research in the field of racial biology; further development of racial hygiene measures; a total stop to immigration; increased public economic support for family formation; and a more efficient housing policy. ${ }^{35}$ These policies are linked to the perception that unrestricted growth of modern big cities was a huge threat not only to the racial quality of the nation, but also to morality and culture. The modern city was seen as a sewer of criminality and decadence that had to be cleansed through a number of measures. In this context the political vehicle of eugenics became very versatile.

33 Engdahl, Sverige och det tjugonde århundradet, 313-14.

34 Engdahl, Vad vi vilja!, 4-5; Per Engdahl, 'Nysvenskheten - en samlingsparoll för nationell förnyelse,' Vägen Framåt 1 (6 June 1932); Per Engdahl, 'Livsnerven i nationen,' Vägen Framåt 1 (15 August 1932).

35 Engdahl, Vad vi vilja!, 5 . 
In Engdahl's view, two groups should be especially targeted through negative eugenic measures: the Gypsies and the so-called 'Tattare'. ${ }^{36}$ Here, Engdahl falls into the general Swedish context of his time, since these groups, at least on a rhetorical level, were frequent targets for eugenic measures in general and sterilization in particular. For the 'Tattare' group especially, it is also obvious from both Engdahl's writings and the wider Swedish context that the distinction between social and racial underpinnings of eugenic measures is not clear cut. The perceived societal problems of the 'Tattare' group, including criminality, asocial living, feeblemindedness and unemployment, could be explained and tackled both from a social and a racialist perspective. But for Engdahl, the racialist perspective dominated. ${ }^{37}$

As for the Jews, Engdahl concludes that the Jews are not a pure race but 'a mixture of Oriental and East Mediterranean', and because of this they should rather be perceived as a people rather than a race. Following this line of reasoning, Engdahl arrives at the conclusion that the Jewish 'problem' was not racialist. He undermined any anti-Semitic theory that relied on a basic racialist perception, including that of national socialists both in Germany and Sweden. This does not mean, however, that Engdahl discarded the Jewish 'problem'. But it means that his anti-Semitism followed a much more traditional pattern whereby the Jews were considered more as a cultural, social and, perhaps primarily, economic threat to the Swedish nation rather than as a racial danger. ${ }^{38}$ Due to their lack of a homeland, Engdahl argues, the Jews are a wandering people and will therefore be strangers wherever they go. But he expresses high regards for the Zionist movement since it has the same nationalist fervour as New-Swedish Socialism. Also, even if Engdahl does not say this explicitly, he presumably realised that if the Zionist movement should succeed in creating a Jewish homeland in Palestine, pressure could be put on Swedish Jews to emigrate. In the meantime though, the Jewish problem should be handled with 'chivalry and justice' and each Jew should be judged on his own merits: 'A Jew that acts in a loyal way and contributes with useful labour should be protected in the same way as other loyal citizens, a Jew that behaves like a bastard should

36 The category of 'Tattare' could roughly be equated with the UK travellers, since they usually led a nomadic and assumed bohemic lifestyle. See further Gunnar Broberg and Mattias Tydén, Ö̈nskade i folkhemmet: Rashygien och sterilisering i Sverige (Stockholm: Dialogos, 2005).

37 Engdahl, Sverige och det tjugonde århundradet, 320-21.

38 Engdahl, Sverige och det tjugonde århundradet, 318-319. Further on the different types of anti-Semitism discernible within Swedish interwar ultra-nationalist and völkisch circles, see Lena Berggren, Blodets renhet: En historisk studie av svensk antisemitism (Malmö: Arx Förlag, 2014). 
be treated like all other bastards.' ${ }^{39}$ With the difference that 'Jewish bastards' contrary to all kinds of Swedish criminals were alien and should be expelled from the country no matter how long their families had been residing in Sweden.

To sum up, we can here assert that Engdahl embraced racialist thought which resulted in general political demands for the preservation of the race such as a stop to what little immigration there was in the 1930s to Sweden and demands for a strong eugenic programme. Furthermore, there is indeed an anti-Semitic strand visible in Engdahl's thought already in the early 1930s, but it is not very prominent and it is largely non-racialist, following a more traditionalist path. 'New-Swedishness' must thus be considered much less racist than Nazism. Instead of becoming a racial determinist, Engdahl emphasizes, and leaves much more room for, the personal abilities of the individual in the process of shaping society and politics:

Finally it should also be emphasised that race is not an end in itself, that race can never become the foremost factor within an idealist vision. Race is that material which builds the people; it is the marble in the artwork. But it is not the material that makes the sculpture a piece of fine art, it is the features that have been chiselled out in the shapes of face and body that mirrors the great artist himself. And so is the race but that material out of which the nation is chiselled out into that splendid piece of art that it was designed to become. ${ }^{40}$

Engdahl and the New-Swedish movement thus acknowledged 'the issue of race', but at the same time rejected 'the myth of race'. ${ }^{11}$ This distinction was further used to differentiate New-Swedishness from Nazism, which Engdahl considered to be trapped within the racial myth. ${ }^{42} \mathrm{New}$-Swedishness is much less deterministic than Nazi ideology in its views on history and much less dogmatic in its views of the future. One way of expressing this difference is to say that the New-Swedish utopia is weaker and less clear-cut. Another way of expressing this difference is to say that New-Swedishness provided a flexible version of fascism. New-Swedishness is more open than Nazism to the fact that societal change will continue, and its political programme tries to create a

39 Per Engdahl, 'Nysvenskarna och judefrågan,' Vägen Framåt 2, no. 5 (15 May 1933).

40 Engdahl, Sverige och det tjugonde århundradet, 321.

41 Engdahl, Vad vi vilja!, 18.

42 See for instance Engdahl, Sverige och det tjugonde århundradet, 227-28 and Engdahl, Från den industriella revolutionen, 36 . 
political system in which there is room for change and adaptation. This flexibility could be explained partly by the New-Swedish position on race. A strong racialist stance seems to lead to a rigid conception of historical development as governed by the struggle between different races and not much else. It also leads to a 'fixed' utopia in the form of the realisation of the racial state, and once this is accomplished there is little left to do for the movement, hence the 'stronger' utopian programme of Nazism which builds on a fundamentally racist vision.

\section{Organisation of Society and State}

This is not to say that New-Swedish Socialism actually succeeded in creating a flexible model for structuring society and state. But Engdahl's plan for a corporate society was an attempt at creating a modern society that was better able to solve the problems of the time, curb the negative influence of capitalism, create a cross-class people's community and accommodate further technical, industrial and cultural development than its liberal counterpart. The development of the corporate system was not to come overnight but was to be a slow process, and this is the essence of the fascist 'gradual revolution' - a new society is to be built piece by piece, step by step.

Corporate society was built on three underlying structures or pre-conditions. First, we have the notion of class-cooperation. Engdahl was a vehement opponent of class struggle and a traditional class-based society since this constituted a threat against national unity. Instead, the corporate society should be built by the joint struggle of the people's community where worker and industrialist were to stand shoulder to shoulder. The levelling of class distinctions was also to include cultural and social levelling, which in effect meant that a fascist society would also have to alter social codes and modes of social conduct. ${ }^{43}$

This notwithstanding, at first sight the corporate system looks a lot like a class-based society with workers, clerks and industry owners represented within every corporation. The difference lies primarily in the value system surrounding the division of labour. As mentioned earlier, fascism uses nation rather than class as its prime societal structuring tool. This, in combination with fascism's essentially organic view on society, leads to the perception that society, as a living organism, cannot function without a plenitude of tasks being carried out. But just as every part of an organism is equally essential for 
the function of the whole and thus equally valuable, every form of labour within a society should be held in the same high esteem. Moreover, fascism generally values manual, physical labour more than intellectual labour. Even if Engdahl, most probably due to his own social and personal background, acknowledged intellectual labour more than his Nazi counterparts, he also embraced the principle of the ennoblement of labour which constitutes the second pre-condition of Engdahl's corporatist doctrine. This principle means that labour for the individual is not simply a means to earn a living in order to survive; it also has character building features and binds the people together within the people's community. Labour is also a principal prerequisite for inclusion in the people's community. Accordingly, it can be seen as a qualifying characteristic that distinguishes the people from the threatening masses.

A further precondition of Engdahl's corporatist doctrine is related to the alternate value system as well as to the principle of the ennoblement of labour and can be described as the meritocratic principle. In accordance with this principle, heritage, wealth, contacts and family ties were of no value when it came to an individual's position in society; the only thing that mattered was personal ability. This principle is dependent on a rejection of existing class structures, and was meant to greatly enhance the individual's possibilities of working his way up within the corporate system. But the meritocratic principle is also an important sifting tool, ensuring that only those individuals that have proven themselves are to hold the highest positions within society and, above all, within the state administration. ${ }^{44}$

The powerful state was, as we have seen, to be a regulating and directing power within society, but its structure was to grow out of the corporate organisation of society. But in contrast with corporate society, which was a modern construct designed for the future without any real historical examples to build on, the powerful state, which Engdahl called the people's state, was seen as deeply rooted in historical tradition and the distinctive character of the Swedish nation.

According to Engdahl, Swedish political history consisted of the interplay between two governing principles, which he labelled the 'people's state' and the 'class state' 45 The first was characterized by strong but altruistic leadership and close ties between the leader/king and the depths of the people, while the second was characterized by parliamentary rule which led to national degeneration through single-class domination and class egoism. Historically, the

\footnotetext{
44 Berggren, 'Building a New Society', 125-29.

45 The following description of the people's state is, unless clearly stated, based on Engdahl, Sverige och det tjugonde århundradet, 241-301.
} 
parliamentary system had been supported by the aristocracy, but since the role of this class had been down-played by historical development, the modern class-based political parties had taken its place. The fascist state was seen as the carrier of the people's state tradition, whereas the democratic parliamentary system was seen as but the latest example of the class state tradition.

Engdahl digs deep into Swedish history to find the actual roots of these two types of government, and he claims that these two principles were actually present even before the Swedish nation was formed by the unification of the Swede and Geat tribes under the Swede king Eric the Victorious in the late tenth century. According to Engdahl, the Swede tradition was that of the people's state, whereas the Geats had a much stronger tradition of aristocratic rule. He traces the people's state tradition through history and gives numerous historical examples to learn from. Among the more prominent of these are Gustav Vasa, founder of the modern Swedish national state Gustav II Adolph, creator of Sweden's status as a European super power in the seventeenth century, and the 'warrior king' Charles XII.

The state of the Swedish monarchy had deteriorated since the late eighteenth century however, and even if the contemporary king Gustav V was held in quite high regard, Engdahl seemed to be of the opinion that the monarchy had outlived its usefulness. It was to be retained, but more as a symbol of national unity and historical tradition. ${ }^{46}$ The monarch was to be involved in the appointment of the government, but was to be much less powerful than the government in directing the affairs of the state. The government was to be headed by a strong prime minister, but it is striking that Engdahl has very little of the strong leader rhetoric that is so common within Nazism. ${ }^{47}$ Engdahl is unmistakably elitist and we have earlier encountered his Superman-rhetoric, but even if the prime minister has a very influential position, he is to be flanked by others.

There was to be only one political movement and the government of the people's state was to grow from this movement. The government was to be more or less independent from parliament. At its side, it was to have two supplementary advisory bodies, the Riksrådet [national council] which would represent the political movement and the Näringsrådet [trade council] which was to represent the corporations. The parliament in its turn was to consist of two chambers. The lower chamber, the Chamber of Labour, was to be nominated by the corporations and would represent society's material interests. The upper

\footnotetext{
$46 \quad$ Engdahl, Det nya Sverige, 21.

47 For a discussion on the notion of the strong leader, see Berggren, 'Building a new Society', $132-34$.
} 
chamber, the Chamber of Culture, was to be nominated by the major NGos; the free churches, the teetotal movement, the local folklore movement, the sports movement, the popular education movement and the housewives movement and would represent the spiritual and cultural side of society. The chambers were to work in unison and were to have restricted possibilities to limit the powers of the government should it yield to the abuse of power and thus function as 'a societal safety valve against degenerative despotism.'48

The 'new' people's state is to be built to last and adaptability to political, economic and social change was necessary for its survival. The flexible strand within Engdahl's thinking should also be seen against another background. According to Engdahl, the New-Swedish people's state would further the positive influence on society and state of one of the more important driving forces of historical development, the interplay between the collective community and 'strong personality'. This interplay cannot take place within a framework that is too rigid, and what becomes discernible here is a syncretic ideological ambition where individualism and collectivism are to be harboured within the same system: 'The demand for unrestricted development of the individual personality while adhering to an unswerving loyalty to common good, to the whole, is in a few words the attitude of the new times to the problem of the relationship between individualism and collectivism. ${ }^{49}$

\section{Building a Nation: Enlightenment and Social Security}

The corporate society and the people's state would, according to Engdahl, create a society where modern industrialism could thrive, where the national community and national culture could find its ultimate realisation, and where Sweden could once again play a decisive part in the historical development of northern Europe. And even if Engdahl frequently claims that the defeat of democracy and the subsequent rise of the people's state is a natural historical process and that the corporate system is nothing but 'a fulfilment of the strife for concentration and specialisation that characterises the later stages of industrial development', its success nevertheless depends on the activism of the movement. ${ }^{50}$ This activism is dependent on the individual personalities that uphold the movement, but the success of the 'new ideas' is also dependent on large-scale popular support from the Swedish people. Through its

\footnotetext{
48 Engdahl, Det nya Sverige, 22.

49 Engdahl, Sverige och det tjugonde århundradet, 328.

5o Engdahl, Från den industriella revolutionen, 28.
} 
activist ideal the movement itself epitomises the rise of the 'New Man', but it must also embark on a mission of national enlightenment to educate the masses.

We have already encountered Engdahl's ideal man - loyal, steadfast, dutiful and deeply rooted in the people's community - and I will not dwell on this any further. What needs to be said though, is that New-Swedish Socialism, like other kinds of fascism, places extremely high demands on its followers. The success of the movement is dependent on a large following that is willing to do the work and share the same value system. Using the terminology of the Italian philosopher Antonio Gramsci, we could say that of all political ideologies fascism is probably the one which has the biggest need for a combination of political and cultural hegemony. Therefore, we will now turn to the last piece of the New-Swedish jigsaw, the democratization of the people through the ennoblement of the masses. ${ }^{51}$

Due to the depravation of the time, many Swedes had turned to shallow values and simple pleasures, creating a society where greed and selfishness had become commonplace. We have already seen that Engdahl was of the opinion that durable change had to grow from the bottom up, and it was thus considered essential for a lasting result that the new society gained momentum not only through political practice, but also through the creation of cultural hegemony. In order for this to happen, the masses (at least that part of the masses that was not excluded) had to be transformed into the people. Engdahl was sure this would be a smooth transition. After all, it was not loyalty to the movement that was required; it was loyalty to the nation. Since Engdahl held the view that the values and qualities of the Volksgeist were implanted in every single member of the national community, it was simply a matter of enlightening people about facts and values that were already there in their sub-conscience, but to which their vision had become blurred by the depravation of the time.

In order for the loyalty to the nation and thus the adherence to the people's community to increase within the nation, Engdahl suggested reforms within three areas. First, the educational system had to be strengthened and complimented by the creation of a compulsory youth movement which would invigorate the national spirit of the young through outdoor activities and physical education. For young adults, a similar scheme was suggested in the form of a compulsory labour service. Other means considered essential for the reawakening of the national spirit once the movement gained momentum and actually could influence politics were eliminating unemployment and

$5^{1} \quad$ Engdahl, Sverige och det tjugonde århundradet, 327. 
implementing policies for social security. The fight against unemployment was particularly important, given the principle of the ennoblement of labour and the meritocratic principle that underpinned the corporate system, but it was also seen as essential to create economic and social security since this would bring calm and trust in the political system. And since the political system would be ultra-nationalist, this trust would transform into loyalty to the nation. ${ }^{52}$

\section{Concluding Remarks}

Even if there are outbursts of extreme political rhetoric here and there, we encounter a remarkably reasonable and 'low-voiced' fascist in Per Engdahl. Engdahl's tone is in tune with the general political debate of his time, and his intellectual and academic tone also seems to have rendered him a voice within the more established political debate in interwar Sweden. His version of fascism was shaped by his personal background, the upper middle-class upbringing and his academic studies. We have encountered his comparative moderation when it comes to the issues of race and anti-Semitism, his 'flexibility' in the reconstruction of society and state institutions, the granting of moderating powers over the government, although heavily restricted, to parliament, and so on. His tone would, however, sharpen during the 1930s, and during the war his political rhetoric was to become more aggressive while parts of the political programme of the movement became radicalised. However, there can be no doubt that Engdahl was already a fully-fledged fascist already by the early 1930s, and to conclude we will now return to the definition of fascism given in the beginning of this article and measure Engdahl's ideological thought against it.

Engdahl holds a basic ultra-nationalist position. He rejects core liberal and humanistic beliefs and liberal democracy, and his nationalist vision is also coloured by racist thought. This ultra-nationalist position also functions as a direction indicator for the revolutionary upheaval that, according to Engdahl, has become necessary due to the listlessness and depravation of contemporary society. In order not to disrupt the nation's ties to historical tradition however, this re-shaping of society was not meant to be a sudden upheaval but a gradual process which respected the organic nature of state, society and people. It was nevertheless revolutionary, since it meant a clean break with the old liberal order and the rebirth of the national community through the creation of a 
people's community in a modern corporate society under the leadership of the powerful people's state. And the whole process depended on the rise of a new breed of Supermen, racially (but not necessarily physically) superior, dutiful, steadfast and unswervingly loyal to the nation.

In this article, I have shown that Engdahl's ideological thinking includes all the un-eliminable core concepts of the ideal-type definition of fascism given at the beginning. Following Michael Freeden's model for ideological analysis, I have also discussed how these core concepts interacted with and thus qualified each other, rather than simply using a 'check-list approach', i.e. seeing the defining concepts as mutually independent entities that can be ticked off a list. Engdahl's revolutionary thrust, for instance, is determined by his ultranationalist conceptions of history and historical development as well as the holistic and syncretistic pretentions of the ideology. The outline of the new society is dependent on it being a vehicle for the rebirth of the national community, and the vision of the New Man depends both on Engdahl's ultranationalist ideals and the task that this New Man is set to fulfil within the new society.

Engdahl's New-Swedish Socialism should not be fitted into any of the wider categories of Italian-styled Fascism or German-styled Nazism. For sure, there are influences discernible from both, and Engdahl is also very clear that they all belong to the same ideological family. Nevertheless, time and again he stresses the uniquely Swedish character of the New-Swedish movement and its independent position in relation to Fascism and Nazism, both internationally and within Swedish borders. If there is a role-model, it is Fascist Italy rather than Nazi Germany. What we have here is a form of indigenous fascism unique to Sweden, and a its distinctive features would be its comparative moderation in tone and action, its unmistakably intellectual character and 'flexible' approach to political reform, as well as a strong focus on the social and economic reshaping of society through corporatism. 